\title{
The Characteristics of Indonesian Legal Language in Notarial Documents
}

\author{
I Wayan Ana' ${ }^{1}$, Ida Bagus Putra Yadnya ${ }^{2}$, I Made Budiarsa ${ }^{2} \&$ Ida Ayu Made Puspani² \\ ${ }^{1}$ English Department, Faculty of Letters, Warmadewa University Denpasar, Indonesia \\ ${ }^{2}$ School of Postgraduate Studies, Faculty of Letters Udayana University Denpasar, Indonesia \\ Correspondence: I Wayan Ana, University of Warmadewa, Bali-Indonesia, Indonesia. Tel: 62-812-3826-762. E- \\ mail: ana.wayan@gmail.com
}

Received: July 4, 2020; Accepted: July 19, 2020; Published: July 20, 2020

\begin{abstract}
This study is aimed at finding out the characteristics of Indonesian Legal Language in notarial documents. This study is theoretically based on Cao's theory (2007) in her book entitled "Translating Law", and supported by Djatmika in his book entitled "Prilaku Bahasa Indonesia, dalam Teks Kontrak". The data of this study were collected from 6 ( six) legal documents in the form of lease agreement, sale agreement, prenuptial agreement, deed of company establishment, employment agreement and conciliation agreement. From the results and analysis, two (2) characteristics were found in the ILL of notarial documents: (1) general characteristics (boilerplate) and (2) specific characteristics. There are fifteen (15) specific characteristics of ILL found in the notarial documents in this research. The fifteen characteristics consist of eight (8) lexical characteristics and seven (7) syntactical characteristics. The lexical characteristics found in the notarials documents are (a) the use of legal terminologies, (b) the use of repetitive words (tautology), (c) the use of words dan/atau "and/or", (d) the use of synonymous words, (e) the use of foreign terms, (f) the use of sebagaimana word, (g) the use of the word mana as demontrastrative adjective, and (h)the use of formal address; while the syntactical characteristics consist of (a) the use of long and complex sentences, (b) the use bahwa clause, (c) the use of passive sentences, (d) object fronting, (e) declarative sentence beginning with verb, (f) the use of reference system and (g) pre-supposation.
\end{abstract}

Keywords: legal language, notarial documents, lexical characteristics, syntactical characteristics

\section{Introduction}

\subsection{The Background and Problem}

Language plays a significant role in law-making and regulation in society. People can understand, enact and preserve law in a social context only through the use of a language (Natabaya, 1998). The language used in the field of law is called legal language. Legal language is a normative language (Zidan, 2015), as it is closely related to norm creation, norm production and norm expression (Jori, 1994). Mahadi, et.al (1979) proposed that legal language is a specific language register used in the world of law, either in the form of scientific work, legislation, prosecution (requisitoir), defense (pleidoi), documents used in legal cases, such as, claims, counter claims, conclusions (conclusions), terms of art or skills in professions such as draft and legislation conceptors, judges, prosecutors, lawyers, notaries, police, legal journalists, law students, and so forth (Mahadi and Ahmad, Sabaruddin, 1979; Zidan, 2015).

Indonesian language used in the field of law and legislation in Indonesia or commonly referred to as legal language is Indonesian language. It is used in various legal and regulatory products (Suhaemi, 2009). Indonesian Legal Language is one of the language registers used for communication in the field of law (Adiwidjaja and Hartini, 2003). Indonesian Legal language, like other language register is a scientific language therefore it must comply with the structure and standard rules of Indonesian language (Hadikusuma, 1992). Although Indonesian Legal Language (ILL) is basically Indonesian, there are clear distinctive features between ILL and Indonesian language that serves as differentiators, which includes the concept of language itself. Indonesian has a poly-semantical concept, one word could have several meanings, while it should be avoided in legal language, if possible. Since legal language has mono-semantic concept or unity of meaning (Nasution and Warjiyati, 1998; Natabaya, 1998; Adiwidjaja and Hartini, 2003; Suhaemi, 2009). This is intended to prevent ambiguity regarding the rules of law. 
Notarial documents, in Indonesia, are legal documents as they contain laws governing the rights and responsibilities of the parties engaged. They are certainly comprised of legal language. Under the Law of the Republic of Indonesia Number 30 of 2004 amended by the Law of the Republic of Indonesia Number 2 of 2014 concerning Notary Office, it is stated in Article 1 point 7 that "a notarial document, hereinafter referred to as a Deed, is an authentic document drawn up by or before a notary in accordance with the form and procedures set out under this Law". As legal documents and state archives, notarial deeds shall be drawn up using formal Indonesian language in accordance with ILL register.

Notarial documents constitute private legal documents serving various functions, such as, to make, grant, amend, waive legal rights and obligations and to state such rights and obligation (Cao, 2007). These documents are very paramount to protect the rights or enforce the obligations of the parties to the contract. The use of words in a notarial document must contain meaning that can apply and bind the parties to the deed. Even an agreement may bind other parties having an interest to the parties concerned. That is why errors in the language of a notarial document may result in the document being considered null and void.

Relevant and similar studies on the use of the Indonesian language in the notarial documents have been carried out by many reseachers, i.e., Suhaemi (2009: 7) examining the use of Indonesian language in a notarial document. Suhaemi (2009) suggested that the Indonesian language used in the notarial document does not fully comply with (standard) Indonesian rules of language. Deviations are found in the rules of spelling, sentence structure, word choices (diction), and terms of art. The use of Indonesian in the legal field was also examined by Setiadi (2014), in particular notarial documents, the results revealed that the highest errors were found from the aspects of words spelling, word choices and sentences. Both of these studies emphasize their analysis on the errors of Indonesian language used in notarial documents.

From the description above it is required that ILL in a notarial document must be in accordance with good and correct (standard) Indonesian language rules. But the reality from the results of two previous research there were many incorrect Indonesian rules.

As described above, the two previous studies discussed errors found in the notarial documents. This study, however, does not examine whether or not they are correct or effective in a notarial document. This study treats said errors as idiosyncracies of notarial documents, therefore it focuses the problems as follows:

(1) What are the general features of ILL in notarial documents

(2) What are the specific characteristics of ILL in notarials documents.

These characteristics of ILL are very important to know since they special features distinguishing ILL in notary documents and in other legal fields. In addition, the study on the characteristics of ILL in notarial documents has never been conducted by other researchers, so, the result will be of much important for other researchers to conduct further study on ILL.

\subsection{Review of Related Literature}

Legal language refers to the language of and related to law and legal process (Cao, 2007). So, legal language may include any language used in legal communication. In Indonesia, the language used as a legal language is Indonesian language. For this study the Indonesian used for legal purpose as proposed by Cao (2007) is called Indonesian Legal Language (ILL). In fact, both Indonesian and ILL are the same. ILL is also Indonesian language. But it is related to normative, performative and technical nature of language use (Cao, 2007) as well as legal culture which distinguishes it from Indonesian language in general.

ILL can be distinguished based on its nature, as it has clear, cohesive, simple and formal nature. For this study, the theory of Cao (2007) in her book entitled "Translating Law" is applied as the basis for the analysis, and supported by the concept of Djatmika in his book entitled "Prilaku Bahasa Indonesia, dalam Teks Kontrak". He stated that legal text is a type of text requiring clarity, accuracy and effectiveness of language for readers both readers within the scope of legal discourse (judges, lawyers, notaries and so forth) and those outside the scope of this discourse (layperson) (Djatmika, 2012). Clarity (of meaning) means that ideas and information are conveyed clearly by using sentences showing part of the sentence expressly making it easier for readers or recipients to understand the contents conveyed. This quality requires that legal language sentence must be accurate, so that the recipient can understand and comprehend it easily; the nature of cohesiveness of mind, is that as a scientific language, ILL should be composed carefully and precisely, so that it has a unity of meaning that is clear or does not conflict to each other; the nature of simplicity is that the meaning of sentence is simple or as it is. One sentence in legal language must have one meaning, composed in a simple and clear sentence, not too long. Simplicity in term of 
language is straightforward and mono semantic; the last nature is formality that is, the legal language should use official language with words and standard Indonesian sentence structure.

ILL used in notarial documents has the same nature as ILL used in other legal fields. But its features and characteristics may be different. The features and characteristics of notarial documents as the object of this study will be further discussed in the result of this study.

\section{Method}

The method applied in the study of characteristics of Indonesian Legal Language is descriptive-qualitative. The application of this descriptive method is aimed at describing the characteristics of Indonesian legal language found in the corpus of data. Qualitative method is selcted based on the characteristics of qualitative research in which the data analysis in qualitative research is based on the detail description by comparing to the theory of legal language. The technique applied in data collection is note taking technique, by writing down sentences containing the characteristics of Indonesian Legal Language found in the corpus of data. Then the collected data are classified according to the types of characteristics and analyzed based on the theory applied.

There are 6 (six) notarial documents used as corpus of data for this study. The six documents are in the form of lease agreement, sale agreement, prenuptial agreement, deed of company establishment, employment agreement and conciliation agreement. All of these documents are personal legal documents according to the classification proposed by Cao (2007) classifying legal documents into: (1) domestic and international law documents, (2) personal legal documents, (3) legal documents for law students, (4) legal case documents. The documents were collected from notary offices for three regencies in Bali Province-Indonesia. The data procurement process is carried out by submitting an application letter to the notary offices asking and simultaneously requesting the notarial documents. Since documents are confidential, notaries name is not mentioned in this study.

\section{Results and Discussion}

Based the results of study it is found that the characteristics of ILL in the notarial documents can be classified into two: (1) general characteristics, namely the characteristics found in all notarial documents and these characteristics are all the same. According to Cao (2007), they are referred to as standard characteristics (boilerplate). These standard characteristics are found at the opening and closing of notarial documents, as illustrated in the following examples:

\section{(a) PERJANJIAN SEWA-MENYEWA}

Nomor: ...

-Pukul 13.30 (tiga belas lewat tiga puluh menit) Waktu Indonesia Bagian Tengah.

-Pada hari ini, Jumat, tanggal dua Pebruari tahun dua ribu delapan belas (02-02-2018).

-Berhadapan dengan saya, ， Sarjana Hukum, Notaris di Kabupaten Badung yang berkedudukan di Kuta, dengan dihadiri oleh saksi-saksi yang nama-namanya akan disebutkan pada akhir akta ini: (ANS : 1-3)

(b) DEMIKIANLAH AKTA INI.

Dibuat sebagai minuta dan dilangsungkan di Kuta, pada pukul, hari, tanggal, bulan dan tahun tersebut pada bagian awal akta ini dengan dihadiri oleh:

1.

2.

-keduanya pegawai Notaris, untuk sementara berada di Kuta, yang saya, Notaris kenal sebagai saksi-saksi.

-Segera setelah akta ini saya, Notaris bacakan kepada para penghadap dan saksi-saksi, maka akta ini ditanda tangani oleh para penghadap, saksi-saksi dan saya, notaris, serta para penghadap membubuhkan cap jempol tangan kanannya pada lembaran tersendiri yang dilekatkan pada minuta akta ini.

-Dilangsungkan... (ANK, 79- 84)

Example (a) is the opening of a notarial deed. It consists of title and number of the deed. The title and number of this notarial document describe the type of document and the number given by the notary producing it (Djatmika, 2012). Below the number, time, day and date of the deed is drawn up is clearly explained. So, this deed cannot be interpreted as another deed. Then, underneath is a sentence that says, "Berhadapan dengan saya, 
Sarjana Hukum, Notaris ..." which revealed that the notary and the appearers (the parties) met face to face. The example (b) above is the end of the deed (Nasution and Warjiyati, 1998) or the closing of a notarial document. This section contains a sentence beginning with a word Demikianlah "In witness whereof", and the witnesses who witnessed the signing of the deed.

In addition to the standard characteristics (boilerplate) described above, there are special characteristics found in the notarial legal documents which may not occur in all notarial legal documents, but the level of their occurence is more than once and mostly found in the notarial documents being studied. The ILL characteristics found in the notarial documents can be classified into 2, namely (1) characteristics at lexical level and (2) syntactic level.

\subsection{Lexical Characteristics}

This section discusses the lexical characteristics distinguishing ILL and other scientific Indonesian language registers. These characteristics are not only related to terms of art found and used by those engaged in the legal activities but also other features supporting ILL as a special language register.

\subsubsection{Legal Terminology}

The most popular characteristic of ILL is legal terminology (term of art). Legal terminology is a technical term of which meaning is not well understood by most people who are outside the legal discourse (Van Dijk, 1981; Danet, 1985), such as, ordinary people or laymen in general, but is a daily meals for legal practitioners (Djatmika, 2012 : 57). Alcaraz and Hughes (2002:16-18) classify legal vocabulary into three types: (1) pure technical terms (term of art), including: pasal, ayat, Ketentuan Peralihan, and so forth; (2) semi-technical or mix terms or "legal homonym" (Tiersma, 1989), such as, memutuskan, pengesahan, perijinan, penyelesaian, and so forth; (3) colloquial or daily words used in legal text but their meaning changes when they are used in the legal text, such as, yang menyewakan, penyewa, penjual, pembeli, and so forth.

\subsubsection{Repeated use of words (tautology)}

The use of the same word repeatedly is not an effective feature of standard Indonesian language and does not meet the nature of clarity of a sentence in ILL. A sentence containing tautologi tends to be long and not simple, as illustrated in the example below:

(a) -Bahwa PIHAK PERTAMA bermaksud untuk menyewakan kepada PIHAK KEDUA, sebagaimana PIHAK KEDUA bermaksud untuk menyewa dari PIHAK PERTAMA BANGUNAN tersebut di atas. (ANS: 11)

From the example above it can be seen that the phrases PIHAK PERTAMA and PIHAK KEDUA are repeatedly used. It serves an impression that the sentence of this notarial document is not straightforward. But if the phrases PIHAK PERTAMA and PIHAK KEDUA above are replaced by the pronouns of DIA "he" or "she", then the meaning is unclear. The repeated use of words (phrases) in this notarial deed is aimed at serving clarity of meaning and cohessiveness of mind, so the monosemantic nature as a feature of ILL can be achieved.

\subsubsection{The use dan/atau}

The conjunction words dan/atau "and/or" can be treated as dan "and", as well as atau "or". The slash serves the meaning of choice, for example A dan/atau B means that it can be A and B or A or B. The use of the conjunctions dan/atau "and/or" is quite productive in notarial documents as in the following example:

(a) Para penghadap dengan ini menerangkan telah sama setuju dan sepakat untuk mengadakan perjanjian kerjasama dengan syarat-syarat dan/atau ketentuan-ketentuan sebagai berikut: (ANK: 7)

(b) Semua harta benda yang bersifat apapun yang dibawa oleh Para Pihak dalam Perkawinan, atau yang diperolehnya selama perkawinan karena pembelian, warisan, hibah dan atau dengan cara apapun juga tetap menjadi milik dari para pihak yang membawa dan atau yang memperolehnya (ANK: 28)

From the example (a) the parties entered into a cooperation agreement under syarat dan ketentuan "the terms and conditions" (both must be used) or under syarat atau ketentuan "the terms or conditions" (selection or one of them is used), while in example (b), the way of writing is different, not dan/atau, but dan atau. In case the use of the word dan atau "and or" is not a mechanical error (clerical mistake), this form can be considered as a special characteristic, or a notary producing the document assumed that there is no difference between verbal Indonesian and written. As a result, people write what they heard (verbal language), not what should be written. In the written variety, punctuation is required so, what is written is not differently interpreted. The meaning of a sentence in verbal atmosphere can be supported by the situation of the conversation, while in writing it is not supported any non-linguistic properties therefore it must be completed with punctuations. 


\subsubsection{The Use of Synonymous Words}

Synonimous words are the use of two or more words having similar meanings (synonymy) (Mellinkoff, 2004) to convey one legal concept or for a specific purpose (Haigh, 2009). The series of two words which are synonymous is called duplet and three words are called triplet (Haigh, 2009: 34). From the analysis of notarial documents, it is found that many two or more words that have similar meanings (synonyms) are used in the text, as described in the example below:

(a) --Segala kerugian akibat kelalaian, keteledoran atau kurang hati-hati dari salah satu pihak yang dapat dikwalifikasi sedikit .... (ANS: 40)

(b) --Perjanjian kerjasama ini tidak akan berakhir atau berhenti dengan meninggalnya salah satu pihak ... (ANK: 80)

(c) dan selanjutnya para penghadap juga menyatakan telah mengerti dan memahami isi akta ini. (ANK: 65)

(d) -Pihak Pertama menyatakan dengan ini telah memindahkan, mengoperkan dan menyerahkan kepada Pihak Kedua ... (ANS: 16)

The use of words having similar meaning in the notary document in example (a) - (d) seems not very good, but each of these synonymous words complements each other either as a choice of meaning or by adding the meaning of the first word. In example a), the triplet kelalaian "omission" is synonymous with keteledoran "negligence" and also synonymous with kurang hati-hati "less cautious". Similar synomony is found in the duplet berakhir "expire" or berhenti "terminate" in example b). Synonymous words in example b) provides a choice of termination which means that the period of time is over or is indeed ended by giving a choice of stop that is not necessarily ended but is temporarily terminated and if it is not continued then the agreement will end. In example c), the used of duplet mengerti "understand" is synonymous with memahami "comprehend" but memahami "comprehend" adds the meaning of mengerti "understand". Triplets memindahkan "transfer", mengoperkan "sublease" and menyerahkan "surrender" all mean a movement or change of rights from one party to another, but menyerahkan "surrender" adds the meaning of memindahkan "transfer", and mengoperkan "sublease". There are still many synonimous words used in the notarial documents, one of the most often found is setuju "agree" and sepakat "covenant" having similar meaning. Can one of the synonyms be removed to make the notarial sentence more effective, simple and straightforward? Haigh (2009) says that duplets or triplets in legal language have a single legal concept and a specific purpose. If it is observed closely, it turns out that one of these words can not be removed. For example, the synonimous word in example (c), mengerti "understand" and memamai "comprehend". The parties may understand the contents of a notarial document explicitly but he does not comprehend the purpose of the contents (implied). From the above description, there is a common thread (link) on the purpose of using these synonymous words, namely to clarify the meaning (Mellinkoff, 2004), so that the meaning that comes out is one meaning (one legal concept) (Haigh, 2009) which cannot be interpreted as another that can make one party suffer losses.

\subsubsection{The Use of Foreign Terms}

The use of foreign words (terms) is inevitable in this globalization era. ILL cannot escape from the influence of foreign languages which may affect the choice of words (diction), sentence structure and language style. Even, the use of certain foreign terms cannot be avoided by legal actors, since the concepts contained therein cannot be transferred using other languages than the source language (Haigh, 2009). The choice of foreign languages used in certain laws is very much influenced by the legal system of a particular country, for example, legal English uses many foreign terms derived from Latin and French, while Indonesian legal language (ILL) adopts many foreign terms from the Dutch. This is inseparable from Indonesian state law sourced from Dutch language. The following are examples of terms deriving from foreign languages:

(a) Apabila terjadi keadaan force majeure (yang berada diluar kemampuan) seperti bencana alam, huru hara, peperangan, maka Pihak Pertama dan Pihak Kedua telah sepakat untuk saling melepaskan tuntutan kepada pihak lainnya; (ANS:123)

In the example (a) above, the notary is more interested in using the foreign term force majeure accompanied by an explanation of its meaning in parentheses. Yet according to the Indonesian Dictionary (KBBI) there is a phrase having close meaning to the foreign phrase force majeure, namely, keadaan kahar. Why does the notary not use the phrase in the Indonesian Dictionary (KBBI) that is already legal and official? There are two reasons underlying the choice of foreign term force majeure used in the notarial documents. First, empirically, the term force majeure is more established and easily understood by the parties entering into the contract. Second, under legal theory, the meaning and concept of law contained in force majeure is less accurate if it is translated into the term keadaan kahar. 


\subsubsection{The Use of Word sebagaimana}

According to the Indonesian Dictionary (KBBI), the word sebagaimana is derived from the word bagaimana. This word has the meaning of sebagai halnya "as it does", seperti yang telah dikatakan "as has been said", and sama halnya "the same as". The use of this word is found in the notarial documents, as shown in the following example.

(a) -Bahwa PIHAK PERTAMA bermaksud untuk menyewakan kepada PIHAK KEDUA, sebagaimana PIHAK KEDUA bermaksud untuk menyewa dari PIHAK PERTAMA BANGUNAN tersebut di atas. (ANS: 11)

The word as in the notarial text in example (a) serves as a coordinative conjunction that links two independent sentences. The function of the word sebagaimana in this text (sentence) is the same as the function of coordinative conjunction dan "and" which connects two equal sentences, but in ILL it tends to use the word sebagaimana which is not a conjunction.

\subsubsection{The Use of Questions Word mana as Demontrative Adjective}

The word mana is a type of question word which can be attached with prefix di-(dimana "where"), prefix ke(kemana "to where") and combines with preposition dari (darimana "from where"). However, it has a special function in the notarial documents not as a question word but a demonstrative adjective. See the following example.

(a) Pembukuan mana seluruhnya ditutup pada akhir bulan dan akhir tahun serta dibuatkan neraca dan perhitungan laba rugi yang sebagai pengesahannya ditanda-tangani oleh kedua belah pihak. (AN: ...)

(b) Biaya hidup mana selama 6 (enam) bulan disepakati Para Pihak tidak lebih dari Rp. 60.000.000,00 (enam puluh juta rupiah) (AN: ...)

Pembukuan mana "the bookkeeping" in example a) and biaya hidup mana "the cost of living" are noun phrases using the word mana as demonstrative adjective. The word mana as described above is a question word, but in a notarial documents it has a special function as a demontrative adjective. This is a characteristic that needs to be understood if one wants to understand the contents of a notarial document (deed). So, the two noun phrases can be changed into pembukuan tersebut "the bookkeeping" and biaya hidup tersebut "the cost of living".

\subsubsection{Formal Address}

The characteristic of formality is very significant in ILL and is a requirement in drafting a notarial document, one of them is the use of the address system. There are three addresses used in notarial texts, namely, Nona "Miss" (for an unmarried female), Nyonya "Mrs" (for a married female) and Tuan "Mister" (for both married and unmarried male). The use of these addresses is to show the formal nature of ILL in notarial documents. The address is placed before name, as shown in the example below:

(a) Nyonya Atikah, lahir di .... pada tanggal 08-12-1983 (delapan Desember seribu Sembilan ratus delapan puluh tiga), Warga Negara Indonesia, mengurus rumah tangga, bertempat tinggal di ... (ANK: 15)

(b) Tuan Thomas ...., lahir di Zurich ZH pada tanggal duapuluh delapan Januari seribu Sembilan ratus enam puluh tiga (28-01-1963), Warga Negara Swiss, bertempat tinggal di ... (ANS:17)

(c) Nona Ni Luh Putu ..., lahir di Sibangkaja, pada tanggal 17-12-1984 (tujuh belas Desember seribu Sembilan ratus delapan puluh empat), Warga Negara Indonesia, bertempat tinggal di ... (ANPT: 297)

(d) Nyonya Claire ... Lissac, lahir di Cannes, pada tanggal 13-07-1970 (tiga belas Juli seribu Sembilan ratus tujuh puluh), Warga Negara Perancis, status pekerjaan swasta, bertempat tinggal di ... (ANPT: 12)

The address Tuan "Mister" in example b) is used for a male, regardless of differences in age, and marital status. While for female, Nyonya "Mrs" is used as in examples a) and d) for those who are married. The marital status can be seen from the Resident Identity Card (KTP) or Domicile Certificate for those who do not yet have a KTP, as in example a) and c), while age does not determine, but marital status in the KTP distinguishes a) Nyonya "Mrs." and c) Nona "Miss".

The culture of giving husband's name as the last name for a wife is not generally accepted in Indonesia, as found in western countries, if a woman is married the husband's surname will be attached behind the wife's name instead of the wife's surname, as in example d). Marrital status is not stated in the passport for foreigners. The problem is that it is common by seeing the physical condition or age, a drafter of notarial document directly gives an address of Nyonya "Mrs." or Nona "Miss". This is done as it is not mentioned in the passport and it is impolite to ask marital status to a foreigner. 


\subsection{Syntactic Characteristics}

Indonesian Legal Language (ILL) is the Indonesian language used in the field of law. Therefore, the grammatical structure of ILL is the same as scientific Indonesian register or Indonesian language in general. However, there are certain characteristics distinguishing Indonesian in general from ILL. These special characteristics will be discussed below.

\subsubsection{The Use of Long and Complex Sentences}

Long and complex sentences are not new characteristics in notarial documents. This kind of sentence is found in almost all legal documents so it is difficult to understand its meaning. In addition to being difficult to understand, this characteristic is not the characteristics and nature of legal language which is straightforward, cohesive and effective (short, concise and easy to understand). See the example below.

(a) Kerjasama ini bergerak dalam usaha pengelolaan Hotel, Bar, Restaurant, Spa, karaoke dan usaha yang berkait dengan usaha yang ada pada HOTEL LAVENDER (yang mana hotel tersebut tercatat atas nama Perseroan Terbatas PT. PERDANA DADI, berkedudukan di Kabupaten Badung, yang anggaran dasarnya didirikan dengan AKTA PERSEROAN TERBATAS PT.PERDANA DADI, tertanggal 13-3-1990 (tigabelas Maret seribu sembilan ratus sembilan puluh), Nomor : 123, yang dibuat dihadapan KOEMALASARI, Sarjana Hukum, Notaris di Malang beserta pengesahannya telah diumumkan dalam Berita Negara Republik Indonesia tertanggal 03-09-1991 (tiga Septemberseribu sembilanratus sembilanpuluh satu), Nomor : 71 tambahan nomor 2846, dan telah mengalami beberapa kali perubahan dan perubahan yang terakhir dengan AKTA PERUBAHAN DAN/ATAU TAMBAHAN “PT. PERDANA DADI” berkedudukan di Kabupaten Badung, Propinsi Bali, tertanggal 26-01-1999 (duapuluh enam Januari seribu sembilan ratus sembilan puluh sembilan), Nomor : 11, yang dibuat dihadapan ALEXANDRA PUDENTIANA WIGNJODIGDO, Sarjana Hukum, Notaris di Surabaya, yang semua dokumen-dokumen tersebut, salinan fotocopynya dijahitkan pada minuta akta ini; setempat dikenal dengan Jalan By Pass Ngurah Rai Nomor 7 Kelurahan Kuta, Kabupaten Badung, Propinsi Bali. (ANJ: 18)

Although the sentence in this notarial document is long (consisting of 167 words), the interrelationship among sentences is very clear. Basically, the long sentence above is the supplement to an explanation concerning PT. PERFECT DADI only. Long sentences that are often found in ILL (in this study notarial documents) are not because the sentence in notarial document is always composed in such a way from the beginning, but it is aimed at clarifying the meaning so as it causes no misinterpretation (Hadikusuma, 1992; Natabaya, 1998).

3.2.2 The Use of Conjunction bahwa at the beginning of a sentence (bahwa clause)

Conjunction bahwa "that" is a conjunction that is widely used in the initial part of a legal statement (in this research it is called bahwa clause). However, it should be noted that not all initial statements can be started with bahwa "that". See the following example:

a) -Bahwa antara para Pihak telah terdapat kesepakatan untuk melangsungkan perkawinan dan untuk itu para pihak telah setuju dan mufakat untuk membuat perjanjian kawin ...; (ANk: 16)

In a passive sentence, the conjunction bahwa "that" is a signal that the element that accompanies it is a subordinate sentence filling the subject position. But the sentence in the notarial document above is not a passive sentence. Or bahwa conjunction appears after a clause and functions as a conjunction of a nominal clause. So the sentence becomes: para pihak menerangkan bahwa antara para pihak ... "the parties declare that between the parties ..."

\subsubsection{Use of Passive Sentences}

In general, the use of active sentence in legal drafting is better because the meaning is clearer. But the use of passive in drafting legal documents is very important, particularly if the drafter of legal documents wants to put more emphasis on the object of the sentence and hides the subject. For example, Disahkan di Jakarta "Legalized in Jakarta" (UU: 356) and Dilangsungkan dengan ... "Entered into with ..." (ANKA: 86); The subjects of the two sentences are hidden. The drafter of the text more emphasizes that the law in the first text was passed in Jakarta, by not explaining directly who legalized it, and the second sentence that the deed was entered into... without explaining who entered into the deed. However, the subject of the two sentences can be identified from the context of each legal document. The use of passive sentences in notarial documents is quite significant. This shows that the legal text places more emphasis on what is done (the object) rather than who does (the subject). 


\subsubsection{Object Fronting}

In addition to the use of passive sentences, the ILL in notarial documents also uses sentence structure by fronting the object (put the object at the front position). Although it is not widely used as passive sentences, the object fronting is found in ILL text, especially the notarial documents. See the following examples.

(a) -Berhadapan dengan saya, ..., Sarjana Hukum, Magister Kenotariatan, Notaris di Badung, dengan dihadiri oleh saksi-saksi yang saya, Notaris kenal dan akan disebutkan dalam bagian akhir dari akta ini: (ANJ: 6)

(b) -Setelah akta ini oleh saya, Notaris bacakan kepada para penghadap dan para saksi tersebut, maka segera akta ini ditandatangani oleh para penghadap, saksi saksi dan saya, Notaris. (ANK: 44)

(c) - Para penghadap telah saya, Notaris kenal. (ANS: 20)

The sentence structure emphasizing and fronting the object can actually be transformed into a positive sentence structure that is easily understood by most readers of the notary deed, but this is not done by the notary public, and they tend to maintain the sentence structure by fronting the object as a special characteristic of ILL in the notarial documents. The active form of example a) is -Berhadapan dengan saya, ..., Sarjana Hukum, Magister Kenotariatan, Notaris di Badung, yang sudah mengenal saksi-saksi yang hadir dan akan disebutkan dalam bagian akhir dari akta ini; b) -Setelah saya membacakan akta ini kepada para penghadap dan para saksi tersebut, maka segera akta ini ditandatangani oleh para penghadap, saksi saksi dan saya, Notaris, c) -Saya, Notaris sudah mengenal para penghadap. From the point of view of cohesiveness and clarity of meaning, the structure of positive sentences is indeed better, but once again the notary public retains the characteristics of the language so that until this research is conducted the pattern of object fronting sentence is still used.

\subsubsection{Declarative Sentence Iniatiated with Verb}

Declarative sentences beginning with verbs are found in the text of notarial document. According to Law No. 2 of 2014, there are two types of notarial deeds, namely, the deeds drawn up by parties called akta partij (deeds of parties) and the deeds drawn up by notaries called akta relaas (deeds of relaas). Judging from its structure, under Law No. 2 of 2014 above, the two types of notarial deeds can be broken down into 1) the beginning of deed, 2) comparative, 3) defining the appears, 4) premise, 5) body of deed, 6 ) introduction to the appeares and identifying witnesses, 7) end of deed. At the beginning of the deed or in the opening section according to division of notarial text discourse unit as proposed by Djatmika (2012), the following sentences are found:

(a) -Hadir di hadapan saya, ..., Sarjana Hukum, Magister Kenotariatan, Notaris di Kabupaten Badung, dengan dihadiri oleh saksi-saksi yang saya, -Notaris, kenal dan akan disebutkan pada bagian akhir dari akta ini

(b) -Berhadapan dengan saya, ..., Sarjana Hukum, Magister Kenotariatan, Notaris di Badung, dengan dihadiri oleh saksi-saksi yang saya, Notaris kenal dan akan disebutkan dalam bagian akhir dari akta ini.

(c) -Datang menghadap saya, ...., Sarjana Hukum, Notaris di Kota Denpasar dengan dihadiri oleh saksi-saksi yang saya, Notaris kenal dan akan disebutkan dalam bagian akhir dari akta ini.

(d) -Menghadap kepada saya, ...., Sarjana Hukum, Notaris di Kabupaten Gianyar, dengan dihadiri oleh saksisaksi yang saya, Notaris kenal dan akan disebutkan dalam bagian akhir dari akta ini.

These four sentences are standard sentences found in the notarial documents (deed of parties). These sentences begin with verbs, hadir, berhadapan, datang and menghadap respectively. From the sentence structure, the four sentences above are in the form of imperative sentences because there are no subjects in the sentence. But from the explicit or implicit meanings of the four sentences above, there is no commands at all but statements. If the four sentences above are statement sentences, what are the subjects?

If observed deeply, it appears that the subject of the four sentences above is ellipted. Because from the meaning contained in the four sentences implicitly it can be assumed that those who are "present", "appear", "come to appear" and "appear" are the parties (the parties who draw up the deed). It can also be assumed that the subjects are the parties present before the notary, which according to the notary does not need to be mentioned because what is emphasized in the sentence above is the legal action of being present or appear before the notary, not the legal subject being present.

Whatever the opinion of the standard Indonesian linguists stating that the Indonesian sentences in the notarial documents above are not standard, incorrect, not in accordance with Indonesian rules in general, but in reality that is used by notaries throughout Indonesia from earlier times up to the present. This sentence structure has been common and has become a format pattern structure adopted by all notaries. 
Related to the choice of sentences hadir di hadapan saya "present before me" (a), berhadapan dengan saya "face to me" (b), datang menghadap saya "come to appear before me" (c), and menghadap kepada saya "appear before me" (d) is determined by the place where the document or deed is drawn up. The phrases (a) and (b) are used if the notarial document is drawn up not in a notary's office, but somewhere else, for example in a restaurant, hotel, café or elsewhere provided that the parties entering into the deed are present in front of a notary. The drawing up such document is justified under to the Law of Notary Office Number 2 of 2014. While the phrases (c) and (d) are used if the parties entering into the deeds come to the Notary office stating that they want to make a document or deed, signed before a notary in the presence of a notary and witnesses. Based on Indonesian semantics, the meanings of phrases (a) and (b) are very different, which means that the parties have higher status and position than the notary, while the meanings of phrases (c) and (d) have lower status and position.

\subsubsection{Reference System}

The long sentence structure of ILL in notarial documents can be made very clear, straightforward and coherent in the mind by using reference system. This reference system is used for long terms that are used repeatedly. Notice the example below.
(a) selanjutnya dalam akta ini disebut Pihak Pertama (ANS: 14)
(b) Selanjutnya cukup disebut sebagai "Perusahaan" (ANJ: 40)
(c) untuk selanjutnya cukup disebut "Perseroan". (ANP:37)
(d) untuk selanjutnya kesemuanya ini cukup disingkat dengan "Tanah" (ANJ:57)

The four sentences above constitute a reference system commonly found in the ILL of notarial documents. Example a) is derived from personal data of persons/parties who in the notarial documents must be described in detail, namely "Tuan ....... lahir di Badung, pada tanggal ...., Warga Negara Indonesia, pekerjaan swasta, tempat tinggal di Jalan ........... Desa Kerobokan Kelod, Kecamatan Kuta Utara, Kabupaten Badung, Provinsi Bali, yang saat ini berada di Denpasar. " It is common for one party in a notarial document consists of more than one person or legal entity, this party will continue to appear and be mentioned almost throughout notarial document, so that simplification with reference system is adopted. Similar as example a), example b) derives from a detailed description of a company, c) a detailed description of the limited liability company, and d) derives from a detailed description of plot of land. This reference system is intended to make long sentences describing previous object to become clear, straightforward and coherent in mind making it easier to remember.

\subsubsection{The Use of Pre-supposition Sentence}

To state the meaning of presuppositions or requirements in ILL, the pattern jika .., maka ..., "if ..., then ...", dan the phrase dalam hal dan apabila "in terms of" and "if ..." are often used. The following are examples taken from notarial documents.

\section{(a) Jika dikeluarkan surat saham, maka untuk setiap surat saham akan diberi sehelai surat saham. (ANP: 49)}

The sentence in example a) shows a presupposition sentence consisting of clauses containing the possibility that will occur or the requirements that must be met for the proposition of the main sentence to occur. Subordinate clause comes after the presupposition marker dalam hal "in case" in the example above. Whereas, the main sentence appears after the comma (,) in example a). Although maka "then" is often not explicit in the sentence, the reader implicitly knows that after the clause there is the word maka "then".

\section{Conclusion}

From the discussion above, it can be concluded that ILL is standard Indonesian language. It has specific natures, namely, clarity of meaning, cohesiveness of mind, simplicity and officiality. The deviations from its nature and the rules of standard Indonesian language found in ILL of notarial documents are not considered as errors but they are considered as distinctive characteristics of ILL. The characteristics of ILL found can be divided into two: general characteristics (boilerplate) and specific characteristics. There are fifteen specific characteristics of ILL being found in the notarial documents in this research. The fifteen characteristics consist of eight (8) lexical characteristics and seven (7) syntactical characteristics. The lexical characteristics found in the notarials documents are the use of legal terminologies, the use of repetitive words (tautology), the use of words dan/atau "and/or", the use of synonymous words, the use of foreign terms, the use of sebagaimana word, the use of the word mana as demontrastrative adjective, and the use of formal address; while the syntactical characteristics consist of the use of long and complex sentences, the use bahwa clause, the use of passive sentences, object fronting, declarative sentence beginning with verb, the use of reference system and pre-supposation. 


\section{References}

Adiwidjaja, S. B. D. D. E. S., \& Hartini, L. D. (2003). Bahasa Indonesia Hukum. II. Bandung: Penerbit Pustaka.

Alcaraz, E. and Hughes, B. (2002) Legal Translation Explained. New York: St. Jerome.

Cao, D. (2007). Translating Law. Edited by S. Bassnett and E. Gentzler. Clevedon: Multilingual Matters Ltd. https://doi.org/10.21832/9781853599552

Danet, B. (1985). 'Legal Discourse', in Van Dijk, T. A. (ed.) Handbook of Discourse Analysis. London: Academic Press, Inc, pp. 273-291.

Van Dijk, T. A. (1981). Studies in Pragmatics of Discourse. The Hague: Mouton. https://doi.org/10.1515/9783110826142

Djatmika, P. D. M. (2012). Perilaku Bahasa Indonesia di dalam Teks Kontrak dari Kaca Mata Linguistik Sistemik Fungsional. 1st edn. Edited by R. D. M. E. P. . Santoso. Surakarta: UNS Press.

Hadikusuma, H. H. P. S. H. (1992). Bahasa Hukum Indonesia. II. Bandung: Penerbit Aumni.

Haigh, R. (2009). Legal English. Second. London and New York: Routledge.

Jori, M. (1994). 'Legal Performative', in Simpson, J. M. . (ed.) The Encyclopedia of Language and Lingustics.

Mahadi, P. S., \& Ahmad, Sabaruddin, D. (1979). Pembinaan Bahasa Hukum Indonesia. Bandung: Bina Cipta.

Mellinkoff, D. (2004). The Language of the Law. Eugene: Wipf \& Stock Publishers.

Nasution, B. J. S. H. M. H. and Warjiyati, S. S. H. M. H. (1998) Bahasa Indonesia Hukum. I. Bandung: Penerbit PT. Citra Aditya Bakti.

Natabaya, H. A. S. (1998). 'Bahasa Indonesia Dalam Wacana Hukum', in Kongres Bahasa Indonesia VII. Jakarta: Departemen Pendidikan dan Kebudayaan, p. 12.

Setiadi, F. (2014). Penggunaan Bahasa Indonesia dalam Akta Notaris di Kota Sintang. Universitas Tanjungpura.

Suhaemi, E. (2009). Penggunaan Bahasa Indonesia dalam Akta Notaris. Jakarta: Pusat Bahasa Departemen Pendidikan Nasional.

Tiersma, P. M. (1989). Linguistic Aspects of Legislative Expression. Vancouver: University of British Columbia Press.

Zidan, A. A. Y. M. (2015). A Linguistic Analysis of Some Problems of Arabic-English Translation of Legal Text, with Special Reference to Contracts. Pertama. Cambridge: Cambridge Scholars Publishing.

\section{Copyrights}

Copyright for this article is retained by the author(s), with first publication rights granted to the journal.

This is an open-access article distributed under the terms and conditions of the Creative Commons Attribution license (http://creativecommons.org/licenses/by/4.0/). 